\title{
A pastoral examination of the Christian Church's response to fears of and reactions to witchcraft amongst African people in the Limpopo province of South Africa
}

\author{
Author: \\ M. Elijah Baloyi ${ }^{1}$ \\ Affiliation: \\ ${ }^{1}$ Department of Practical \\ Theology, University of South \\ Africa, South Africa \\ Note: \\ This article is published in the \\ section Practical Theology \\ of the Society for Practical \\ Theology in South Africa.

\section{Correspondence to:} \\ Elijah Baloyi \\ Email: \\ baloye@unisa.ac.za \\ Postal address: \\ PO Box 392, UNISA 0003, \\ South Africa \\ Dates: \\ Received: 13 Aug. 2012 \\ Accepted: 22 Jan. 2013 \\ Published: 24 Feb. 2014 \\ How to cite this article: \\ Baloyi, M.E., 2014, 'A pastoral \\ examination of the Christian \\ Church's response to fears of \\ and reactions to witchcraft \\ amongst African people in \\ the Limpopo province of \\ South Africa', HTS Teologiese \\ Studies/Theological Studies \\ 70(2), Art. \#1317, 9 pages. \\ http://dx.doi.org/10.4102/ \\ hts.v70i2.1317

\section{Copyright:} \\ (C) 2014. The Authors. \\ Licensee: AOSIS \\ OpenJournals. This work \\ is licensed under the \\ Creative Commons \\ Attribution License.
}

Amongst other things, African culture (societies) has been characterised by its perception and fear of witchcraft. Even though the belief in witchcraft is an old phenomenon, its growth is revealed and to some extent mitigated by videos, films and accounts and stories of church ministers. Whilst some Christian worship services have been turned into witchcraft-centred campaigns against witchcraft, a second group perceive witchcraft as a way of getting rid of one's enemies and a third group see it as the root of human misfortune. Indeed ministers (including preachers and pastoral caregivers) are almost 'measured' by their ability to successfully ward off demons (believed to have been sent by witches), as a yardstick for determining whether they are good ministers with a good following or congregation. The first group of people attend church to pray for protection against 'the enemy', the second group approach native doctors to protect their households from attacks by witches, and the third group rid themselves of witches by burning them along with their personal belongings. This article investigates the impact and consequences of a fear of witchcraft amongst Christians in African societies, particularly those in the Limpopo province of South Africa. It also offers pastoral guidelines for a theological response to witchcraft and its life-threatening influence on people in the affected communities.

\section{Introduction}

According to the South African Press Association (SAPA) there is a report entitled 'Limpopo police warn of new witchcraft trends', a grandmother, Mupala Motopela, and her granddaughter, Cynthia Lemaho, who where stoned to death and then set alight by a mob in Maake village outside Tzaneen after being accused of witchcraft (South African Pagan Rights Alliance [SAPRA] 2011:1).

The following direct quotation represents the cry of the mother whose six sons died. During their funeral procession, two other older women followed her closely fearing that she would break away and hang herself:

What have I done to you that you should keep on bewitching my sons? You let my children grow up, then snatch them away! Bewitch me too! Yes, bewitch me, so that I can rest in the grave! (Nyirongo 1999:1)

In analysing one of the Tsonga idioms ' $k u$ va ni valoyi' (which means 'to be with witches' or 'to be bewitched'), Ntsan'wisi (1985:17) is of the opinion that the Tsonga-speaking people as well as many other African tribes not only believe in witchcraft, but being ill, dying or afflicted by misfortune are also regarded as the result of having been 'bewitched'.

One of the waves of fear that shook South Africa was the execution and burning of people suspected of witchcraft in the Limpopo province in 1990. Many lives were lost and properties destroyed whilst the mob-justice system was trying to eliminate witchcraft in the province. That wave left not only its legacy, but its impact still haunts South African and African people. That is why, even today, we still hear words like those spoken by Superintendent Moatshe Ngoepe:

Ninety youths have been arrested in Giyani and one boy is dead after 39 houses were torched in what appeared to be a witch-hunt. From the 39 houses burnt people lost everything - food, blankets, their children's school uniforms and school books. (Mail \& Guardian 2005)

In 1999, a certain Mrs Ramalepa ran away from her family in Botlokwa village, outside Louis Trichardt (now Makhado), for fear of losing her life after her brother had been stoned to death on witchcraft accusations (Associated Press 1999). In another incident, four police officers who were outnumbered by the community were instructed to stay away and to watch on helplessly as the mob stoned to death a Limpopo priest who was suspected of bewitching his 20-year-old relative who had apparently committed suicide at Rankoma village outside Tzaneen. The reporter said: 
The young man had been found hanging from a tree on Christmas night and the community suspected that he died because he was bewitched, and they blamed it on the priest. (Moloto 2010:1)

The stoning incident took place from 07:40 onwards on 31 December 2010 after the mob hearing at the local soccer field.

An episode entitled 'Troubled souls' was screened on SABC 1 on 20 July 2010 at 20:31. This programme exposed how some churches are widely distributing children's recorded confessions of witchcraft. One of the DVDs also claimed that the confession of a woman named Granny Mohlala stated that she had been coached by Pastor M.B. Mphahlele and Adam Malaka before her confession to implicate her mother and children as witches (Leff 2010:1). These allegations are worsened by the fact that some preachers and pastoral caregivers are trying to use the issue of casting out demons and witches as a draw card to attract more followers to their parishes.

In his book entitled Witchcraft, violence and democracy in South Africa, Ashforth (2005:2) examines how most people in Soweto outside Johannesburg and other parts of democratic South Africa deal with their fear of so-called 'evil forces' such as witchcraft. In his analysis, he indicates how this fear challenges both human rights and the democratic state.

The issue around growing suspicions of witchcraft compels me to agree with Leff, Fontleve and Martin (2001:7) when they say: 'Liberation from political tyranny does not result in automatic freedom from the bondage of superstition and urban legend.' Although the issue of witchcraft is a most difficult one to address, there is apparently also a feeling that some people are being accused by jealous neighbours and relatives and that these accusations have grave consequences. This is according to the Limpopo police in their report posted on 23 March 2011 (Mulaudzi 2011:1). Many family and tribal fights have been orchestrated by witchcraft, relationships have been destroyed and witchcraft has been used to instil fear and uncertainty in people (Phaswana 2008:150). Although one cannot dislocate witchcraft in Limpopo from witchcraft in South Africa's other provinces, this article casts its focus on witchcraft in Limpopo. Besides finding out whether witchcraft is really being practised, it is important to identify both the perception and role of the Christian church in ousting witchcraft by consulting church leaders and pastoral caregivers. This article also pays brief attention to the government's role and relevance in dealing with the issue of witchcraft. According to Phaswana (2008:245), there is a need for pastoral counselling for people who fear ancestral spirits and witches. Okeja (2010:8) articulates that even the most educated Africans are not exempt from a belief in witchcraft. Because of the sharp increase in witch killings, particularly in the Northern Province during early 1980s and 1990s, the Ralushai Commission was appointed in 1995; its final report was published in 1996. It is alleged that, even though no census has been reached, the estimated number of self-defined pagan witches in South Africa is between 3000 and 5000. It is also said that South African pagans who self-define as witches argue that Act 3 prohibits
South African citizens from practicing their religion (Leff, Fontleve \& Martin 2001:1). Although the study is focusing on Limpopo, the problem of witchcraft occurs all over our country. For instance, a naked man found in the New Life Worship Centre church in Block X, Soshanguve, was claimed to be a witch (Kekana 2012:1). Secondly, Skhashule Mashile slept in the police station in Acornhoek, Mpumalanga, after being accused of bewitching Mponeng Pebane, whilst the inyanga, Timothy Chiloane, said he helped many people who had been bewitched in his village (Mashaba 2012:20). These incidents render a study on witchcraft not only relevant but also important.

\section{Background}

Many different definitions of witchcraft have been offered, but for the purpose of this study, I will select only a few. The Mpumalanga Witchcraft Suppression Bill (2007) explains it as follows:

[Witchcraft is] the secret use of muti, zombies, spells, spirits, magic powders, water, mixtures etc, by any person with the purpose of causing harm, damage, sickness to others or their property. (p. 2)

Trapido (2010:1) argues that this definition was rejected by self-proclaimed witches on the grounds that it stereotypes witchcraft as being harmful and portrays witches as being a danger to the communities within which they live and work. Another definition was given by Ralushai when testifying before the Truth and Reconciliation Commission in July 1999: 'A witch is a person who is endowed with powers of causing illness or ill luck or death to the person that he (she) wants to destroy' (Leff, Fontleve \& Martin 2001:6). Others view witchcraft as the power of a person to do harm or influence nature through occult means (Makisto 2011:1). Olukoya (2004:174) sees a witch as a person who uses magic for evil purposes or who practises sorcery. Maboea (2002:19) argues that, according to traditional African religion, sorcerers and witches are agents of disruption and destruction in the community. I believe that although the wording of the definitions above differs, the essence remains that same: that the witch is someone who wilfully uses any muti or the magic of an evil spirit to do harm to or inflict ill-will on other people. The Limpopo province (previously the Northern Province) is mostly inhabited by three ethnic groups, which are the Sepedi, the Tshivenda and the Xitsonga. The concept of 'witchcraft' is known as moloi (Sepedi), muloyi (Tshivenda) and noyi (Xitsonga) (Petrus 2009:34). The word moloi derives from the verb loya, which means 'to bewitch', and it is attributed to people who through sheer malignancy, either consciously or subconsciously, employ magical means to inflict all manner of evil on their fellow human beings (Petrus 2009:35). According to Ralushai et al. (1996:4), these people destroy property, bring disease or misfortune and cause death, often entirely without provocation.

Pauw (1975:233) and Olivier (1981:87) argue that witchcraft stems from an inherent quality, and it is widely believed that witches (who are mainly female) inherit their witchcraft powers and familiarity with the practice from their mothers. 
Africans also have a strong belief that one's financial prosperity and wealth invites witches to one's family. When witches are seen to be occupied with bringing down those who seem to be prospering in life, the potential victims avoid the appearance of doing well so as not to incur the jealousy and wrath of witches (Harries 2010:143).

Just like the traditional Vhavenda (as researched by Phaswana 2008), many African people do not perceive an illness or other misfortune as caused by a virus but by the valoyi (witches in Xitsonga). This is why the traditional African people will always consult a diviner to diagnose who is behind the particular pain or misfortune. Some small animals, particularly owls, mongooses and cats, are also said to be instruments through which the valoyi can inflict pain or misfortune on others (Phaswana 2008:149). In most cases, for the diviner to remove and prevent illness and other misfortune brought upon the family by witches, he or she will instruct the family to slaughter either a goat or a cow and brew beer for the ancestors to restore peace and order in the family.

The connection between ancestral spirits, tokoloshis and witchcraft has always been a difficult one to define, but witchcraft can be practised through them. Baloyi (2010:725) and Dovlo (2007:71) agree that older, single women, particularly close family members, are suspected of witchcraft in the African community. In one of her films entitled The end of the wicked, Apostle Helen Ukpabio (in Nigeria) says that she has the power to identify and deliver those possessed by demon witchcraft. She identifies children who steal, are stubborn, lack interest in going to school, break household utensils or keep bad company as being witches who bring death, illness and misfortune to their families (Igwe 2012:1). From the discussion above, one can see that there is a very little that distinguishes witchcraft from sorcery. The difference is that witchcraft is an inherent quality that allows people to change shape, go about magically and invisibly whilst sorcery is the process of using destructive medicines to cause harm to enemies for whatever reason (Maboea 2002:43). Sorcerers can also use poisoned substance or food and give it to a victim with an intention to harm or kill. According to Oosthuizen (1992:100), the poison given by a sorcerer causes pains in the stomach and vomiting blood, and it sometimes have symptoms similar to tuberculosis. Although sorcery is a result of behaviour that is orchestrated by jealousy, it can also be as destructive as witchcraft.

\section{Some of the ways in which witchcraft appears or manifests itself to Africans}

\section{Ku dyisa Xiganama [to poison]}

Xiganama (Xitsonga), tshiganame (Tshivenda) and sekanama (Sepedi) are popularly known as the poison prepared from the brain or liver of a crocodile. This is sometimes referred to as another form of 'vuloyi' [witchcraft]. It is called xiganama because the victim falls on his or her back whilst bleeding from the ears (even the nose and mouth) and dies instantly
(Carstens 1986:4). Petrus (2009:36) argues that, since the use of poison is usually associated with sorcery, the absence of the term 'sorcerer' suggests that the term 'muloi' can be used as a general category for both psychic witchcraft and sorcery. An example of this occurred on 16 July 2010 when two women from Balanganani village outside Vuwani died of suspected food poisoning. According to Muthambi (2010), Ms Hlekani Mathebula and Ms Ndaheni Mihlaba Mudau died after they had allegedly eaten food and drunk a homebrewed traditional beer mutomboti (African traditional beer) and traditional mageu at a funeral. The residents of that area were afraid, and other people who had eaten the same food were rushed to the nearby Elim hospital, a few kilometres outside of Louis Trichardt in Limpopo. This is perhaps one form of daylight witchcraft. In the same vein, it was reported that a certain Mashile and his children were forced to leave their home in Boelang, Mpumalanga, after he was accused of poisoning Mponeng Pebane (Mashaba 2012:2).

\section{Zombies}

A zombi is known as setloutlwana (Sepedi), xidadjani (Xitsonga) and matukwane (Tshivenda). This term is used to refer to a person who is believed to have died, but because of the power of the witch, he or she is resurrected and made to work for the person who had turned him or her into a zombi. It is alleged that these turned people cannot speak because the front part of their tongue has allegedly been cut off. It is believed that they operate at night, and because of the power of the witch, they can leave rural areas and work in urban areas bringing the good rewards of their labour to the witch. It is also believed that most of the people who are turned into zombis were formally hardworking people whose labour was evident from the progress in their homes. It is said that whenever the zombies meet people they knew, they vanish or just become invisible to those who might recognise them (Carstens 1986:5). This implies that these people could be sent (by their masters) to steal or do harm to other people or human belongings without being recognised. In this way, zombies could be used by witches.

Alongside zombis, there is another creature that is also claimed to be a weapon used by witches to inflict bad things on people, named the tokoloshe. The tokoloshe is believed to have originated from the Xhosa but is now widely used by many ethnic groups in South Africa:

Originally a water sprite, the tokoloshe is nowadays often a domestic spirit in the households of witches and warlocks. Usually described as a brown hairy dwarf, it is virtually identical, in habits and appearance. Sometimes the name tokoloshe refers to a dwarf zombie. (Van Hunks 2002:1)

It has been widely claimed that the tokoloshe is usually visible to adults, has a long penis and is fond of stealing milk. In some instances, the tokoloshe is alleged to have been used by witches to have sexual intercourse with women. A case of a woman who claims to have been poked by a tokoloshe in Honeydew, North of Johannesburg, was reported by Nkhwashu (2013:1) under the main headline 'Jealous tokoloshe pokes me'. 
There are also other forms through which witchcraft manifests itself amongst Africans, such as ritual murder, korobela, lightning, et cetera (Carstens 1986:5).

\section{Consequences of a belief in witchcraft \\ It undermines the power of God}

The belief in witchcraft is so strong that people, even Christians (Felicia 2001) sometimes fail to see the saving power of God. Felicia (2001) calls such Christians 'doubleminded Christians' who pay allegiance to the local witchdoctors and sorcerers so they will not be tormented. Preachers and pastoral caregivers whose attention and sermons always centre on witchcraft might think that they are helping people, but they are in fact giving much credence to witchcraft. I personally believe that the more emphasis that is placed on evil works, the more this evil presence is felt by people. In this way, trust and hope in the power of the Lord slowly moves away from the people's hearts because they are always preoccupied with the devil's works in their lives. This is testified by Maboea (2002:19) who says that, if a member of the family happens to be 'bewitched', the traditional healer must step in because it is traditionally believed that only traditional specialists are able to deal with witchcraft whilst ordinary people can do nothing. The truth of this is articulated by Semenya and Letsosa (2012:3) who argue: 'Some church members in times of difficulties would visit witchdoctors for protection or revenge, depending on the information they received with regard to their mystery.'

\section{Lack of freedom}

Some people are even afraid to live and enhance their own lives for fear of being associated with those who are prospering or rich because they might become the targets of witches. The fear of witchcraft is accompanied by the feeling of not being free despite the political freedom that South Africa offers. Okeja (2010:7) acknowledges this fear: 'So much belief, fear and purposeful recourse to the phenomena of witchcraft and magic in Africa I am conversant with.' Ashforth (2005:1) articulates that occult violence is another form of spiritual insecurity. This fear of witchcraft even disrupts some people's freedom to serve God. I am reminded of one family of six people who used to stay in two small huts (traditional houses) and who always argued that they would not build a decent house as this would direct the anger of the witches toward them. My argument here is not to argue how constructing a decent house can be of service to God, but it is to argue that the fear of witchcraft is leading some people to live in unacceptable conditions even though they can afford to avoid it.

\section{Exiled people}

According to Ntlemo (2012:11), the community of Roadhouse in Malamulele (Limpopo) fired their local civic leaders after the leaders refused to deal with witchcraft matters saying: 'If the civic is not telling us that the witches are going, they must go.' In the same meeting, which was attended by the police from Malamulele police station, the community demanded that a Mozambican woman who was accused of witchcraft be expelled from the area. These statements confirm that it is not only the suspected witches who are meant to be exiled but also those who tried to protect them. Maponya (2011) reported that the Tzaneen municipality in Limpopo is trying to locate two families (the Shipalana family from Julesburg and an unnamed family from GaMaake) who allegedly fled from a temporary shelter after having been accused of practising witchcraft. During the witch-hunt, many people allegedly had to flee their own villages to seek refuge elsewhere. Police stations were also a safety haven for them. It is alleged that some survivors of the attacks and their families fled and took refuge in 'witch villages' that did not have running water or electricity (Bureau of Democracy, Human Rights and Labor 2001). Whilst they were banished from their own villages, they found it difficult to carry their belongings with them, and so they lost many goods whilst running in fear. Whenever people live in forced exile, they definitely do not enjoy life because they are also stripped of their rights.

\section{Psychological effects}

'I do not want to be here. Somebody decided that I was a witch. My heart is dead - what I used to know, I do not know anymore.' These were the words of Yadu Masam at Nguni witches' camp in Ghana, a woman who was accused of being a witch. The fact that she indicated that she cannot know what she knew before is a sign of the psychological effects that her accusers had on her (SAPRA 2013:1). This is traumatic, not only for the victims of the witch-hunt but also for the entire community and relatives.

\section{Some Christians consult with traditional healers or sangomas (inyangas) for protection}

One case study recorded and written by Msomi (2008) says:

I have realised that I cannot get adequate help here, since what I am suffering from is isifo sabantu [literally: African disease]. I wish I could get a chance to deal with this illness in an African way. (p. 101)

These were the words of a 50-year-old male (also a Christian) who was persuading the pastor to ask for his release from hospital so that he could receive traditional healing as he believed his illness was related to evil forces from witches. These types of requests are not only common amongst black Christians who believe they are bewitched, but they also serve to indicate that the belief leads many people, including Christians, to seek sangomas and traditional healers during difficult times.

Witches and sorcerers are believed to have such great supernatural powers that no ordinary people can resist or do something against them. Thus, only the traditional healers like sangomas and inyangas are believed to be able to avert or deal with them successfully (Maboea 2002:19). This belief is 
still held even by some Christians and that is why Manala (2004) argues as follows:

The beliefs in witchcraft have serious negative implications as well. Those who are afraid of being bewitched (irrespective of being Christians sometimes) are forced to spend a fortune to acquire the strongest protective muti. (p. 1501)

There are Christians, particularly from mainline churches, who also visit traditional healers and sangomas to seek protection from witchcraft because they feel insecure. The Xitsonga idiom ' $k$ u biya muti' [to fence off or protect a village] implies 'to medicate a village against witches' (Ntsan'wisi 1985:17). Some call this very practice ' $k$ u tiyisa muti' meaning 'to strengthen the village'. Meanwhile the meaning of both the definitions above and the main aim are to prevent or even trap all the witches who attempt to enter the village with the view of bewitching one or more people. In Zulu, $k u$ tiyisa muti is called ukuziqinisa (Msomi 2008:105). That is why the family where the witch has been trapped was believed to be very strong. The inyanga or traditional healer who performed the practice was believed to be strong, and his muti was also very strong (Ntsan'wisi 1985:17). Although the practice of protecting a person from witches can be performed differently, depending on the traditional healer who performs it, most of them do it around the village at nights. I agree with Setiloane (1976:54) who claims that, when the inyangas or traditional healers come at night, they apply their muti or lenaka on strategic points like doorposts, corners of lapas, fields and cattle kraals. If the aim is to protect an individual, the healer will make small cuts on the forehead, legs and joints of the person who is being protected and smear on some fatty substance (called murhi in Tsonga or setlhare in Sepedi) as a way to strengthen the individual (Kgatla 1995:23). The fact that the so-called mainline church has done nothing to interrogate and try to replace the ancestral veneration by something tangible for Christians who believe in witchcraft opens the possibility for those Christians to request assistance from witchdoctors and traditional healers.

\section{Christian churches and witchcraft}

There are different streams of Christian belief around the issue of witchcraft. In this article, I have selected just three streams: The first is the view from the churches which arose from the work of missionaries from the West (Mainline churches), the second is the African Independent Churches and the third is the Pentecostal and charismatic churches.

\section{Mainline churches (missionary)}

The churches initiated by white people from the West, such as the Reformed Church from which I come, do not really regard a discussion about witchcraft as important. Generally, mainline churches, like the Protestant churches that arose from the Reformation, treat witchcraft as mere superstition and allegation (Gijswijt-Hofstra 1999:110). Perhaps one can mention that one of the reasons for the mainline churches' drop in membership numbers is their failure to address the issue of witchcraft, amongst others. Manala (2004) says:
Members leave in their thousands those churches that do not take seriously and address the threat posed by witchcraft. The exodus of members from many mainline churches to the African Initiated Churches and charismatic church is not only well known, but it is also a cause for grave concern for mainline churches wherever they operate. (p. 1502)

The thought of mainline churches on witchcraft is clearly summarised by Tangelder (2012) when he says: 'For the Western mind it is almost impossible to realize the power witchcraft has over the black South Africans.' It can still be argued that, since most of the mainline churches come from the West, their theological thought is rooted within the Western context, and their response to African problems (like the problem of witchcraft) will therefore not be different.

\section{African Independent Churches (AIC)}

Maboea (2002:9) indicates that this class of churches is characterised by three types: Ethiopian, Zionist and Apostolic. There are already more than 7000 AIC churches in South Africa. They derive the AIC name from the fact that they are churches that split or separated from the Western-oriented missions. Their distinguishing mark, according to Oosthuizen (1997:8), is that some of them mix Christian beliefs with ancestor reverence. Others have animistic practices whilst they all have a sense of sharing and caring.

In some of these churches, some traditional ways of dealing with witchcraft are maintained. For instance, just like the witchdoctors used to come to the house during the night and use some muti to protect the family from the influence of witches, they will also come at night, perhaps using water mixed with salt around the family compound to stop witches from entering. Amongst the Zionists, the sprinkling of water mixed with salt in the yard is a common way of protecting oneself from witches. According to these churches and traditional African beliefs, water, salt and ash have powers to protect because they are clean and pure. Firstly, water plays a great role in purification, and this strengthened the belief that water can also be used to secure life (Oosthuizen 1992:60). Secondly, since all impurities are said to have been consumed by fire, ash is thus considered to have the power to purify all evil ailments (Makhubu 1988:80). In the case of death, ash mixed with water was sprinkled around the house and was also used on windows and door posts to protect and prevent evil forces. That is why, before sharing the deceased's clothes, the clothes are sprinkled with ash to ensure that the evil spirit which may have contributed to the person's death is banished completely (Makhubu 1988:90). Thirdly, since traditional healers used salt mixed with water to cure people of various deceases. Salt had been regarded as powerful in eradicating evil forces.

Some people will use ropes around the waist, neck, hands and feet to protect them from being bewitched. This also does not differ much from what the traditional healers did with people who asked for protection against the witches. It is for this reason that even some Christians will have ropes around their waists. According to prophets from the AIC, the more 
cords and ropes that are wrapped around the waist and neck the better the person's chances of being protected from evil afflictions (Maboea 2002:76). When I was studying theology, I had a friend who had a rope tied around him. When asked why he had this rope around him, he responded by claiming that, if he cuts it off, he would die because his parents and a certain prophet had told him so. I have mentioned but a few of the things the AIC do to prevent witchcraft, but there are still many other rituals which they perform as a way to scare away witches and which many Christians from mainline churches and from Pentecostal and charismatic churches perform when they feel threatened. Most of them do this in secret because they do not want their churches and ministers to know that they visit and consult with AIC leaders in times of challenge. I observed this as I was conducting an infant baptism in one of the congregations where I found ropes around the waist of a child. Although the parents argued that the rope would prevent the child from being bewitched, I eventually managed to convince them to cut off the rope before the baptism took place. The small wires that are hung on doorposts and even gates of the Zion Christian Church (ZCC) members are, amongst others, also intended to prevent witches from entering the household.

\section{Pentecostal and charismatic churches}

Olukoya (2004), one of the well-known charismatics who proposed that 'warfare prayers' will be able to defeat witchcraft claimed the following:

One of the greatest strongholds confronting believers is the spirit of witchcraft. It is the spirit of manipulation and control. A witch is a person who uses magic for evil purposes or who practices sorcery. A sorcerer is someone who practices magic with the help of the evil spirits. Witches excel in wickedness. Occult practice is enhanced by the power of witchcraft. (p. 174)

Most Christian preachers and pastors equate the Greek aiwn (literally meaning 'century' or 'epoch') in Galations 1:4 with the source of witchcraft. In this context, the aiwn was used to refer to 'this present evil world'. According to Lundell (2001:68), aiwn refers to the high-ranking evil powers under Satan. The same concept also carried a double meaning in reference to the human leaders (Jewish and Roman) who had Jesus crucified. Romans 8:38, Ephesians 1:21, Colossians 1:16 and Colossians 2:20 also refer to this concept. Another group of Christian ministers usually connects witchcraft with demon possession. In many cases where demons are cast out in contemporary charismatic churches, there will be mention of some witches who resemble such demons. Although it cannot be said with certainty whether all mental illness are regarded as demonic or not, Carstens (1986:37) argues in The spiritual warfare mini-handbook that demons are defined and described as having the power to cause mental illness. Luke 9:39 testifies to this: 'A spirit seizes him and he suddenly screams, it throws him into convulsions so that he foams at the mouth.' Mark 5:1-10 discusses a man who behaved like a madman because of demons. There is a very serious statement by some pastoral caregivers, particularly those who can cast out demons, who are saying that the demons are being sent or accompanied by witches to destroy people's lives. This is why, during some demon-casting ceremonies that I have attended, the casting pastor would ask demons questions, and they would respond by saying how and why they came to that particular person. In most cases, those demons would speak about a relative of that particular person wanting to destroy him or her.

That is why, in some cases, the pastors who have the gift of casting out demons will first ask the demons who they are, what they came to do and so on. The responses of the demons usually indicate that they were sent to fulfil a particular purpose within the possessed person's life. They will sometimes mention names of people who sent them. Pastors casting out demons call their ministry a 'ministry of deliverance and healing'. It has always been believed that, whenever demons are cast out, the person who had been possessed by demons is healed and cleansed.

Demon possession and the casting out of demons are the very links which most Christian pastors use to engage in discussions on witchcraft. Many charismatics believe that every demon that possesses a person has links to witches or had been sent by witches, and hence casting them out is an automatic defeat of the witches who had sent them.

Pentecostals also believe in the power of prayer, particularly fasting prayers, to protect people from witchcraft. It is also common practice that dedication prayers relating to purchases such as the purchase of a car or a house are another way of preventing witches from attempting to access such property. More often, the ministers are called during the evening to come and pray to dedicate houses to God, whilst new cars are taken to the church to be blessed by dedication prayers. Sometimes there is what is called a prayer walk, where the minister will pray whilst walking around the house. He will bless and protect it from evil spirits, which are believed to be in communion with the witches. This practice reinforces in people the belief that such prayers protect their properties and their lives from the evils of witchcraft.

\section{Critical evaluation}

Any discussion about witchcraft always includes the question of whether witchcraft really exists. Although this is not the focus of this study, it is important to mention that, according to the African worldview, witchcraft is a reality. Mwalwa (1999:6) says: 'I am convinced that witchcraft is not imaginary, nor unreal. It is still a strong force in Africa.' Even though it is not easy to observe and point out who the witch is, I believe that witchcraft does exist amongst African people. According to Ralushai et al. (1996:12), the responses to questions concerning the existence of witchcraft indicate that the overwhelming majority of people interviewed still believe in witchcraft.

Whether witchcraft is a reality or a figment of the imagination, the fact remains that those people who believe in it expect scholars to do research in order to help them find ways to avoid criminal offences that are triggered by the belief. 
There are many suggestions which indicate that, although witchcraft has been blamed on both males and females, in the majority of cases, females are mostly blamed for it. Carstens (1986:5) says: 'Women are more accused than men of practicing witchcraft.' Harries (2010:142) also echoes this by saying: 'Older women are most likely to be accused of being witches.' In this way, we can also understand how witchcraft was also used to widen gender disparities in our society.

The most crucial element that contributes to witchcraft as a complex and serious issue amongst the black people of Limpopo is the real fear they have of it. Sometimes pastoral caregivers also use this fear to their own benefit. This is why most charismatic preachers will devote more time to dealing with issues of witchcraft and demon casting than preaching the Gospel in their church programmes. In some churches, demon casting and witchcraft have become the centre of worship services which usually attract many people. I once attended a normal Sunday church service where the bulk of the leading pastor's sermon revolved around spirits.

In contrast, mainline churches simply can ignore the issue of witchcraft, alleging that it is a simple suspicion when it has an adverse effect on the church community. Because people (both Christians and non-Christians) believe in and fear witchcraft, the church needs to take the time to address the issue of witchcraft in order to prevent its members from seeking protection from other churches and from traditional healers.

It is not easy to decide whether someone who is alleged to be a witch is truly a witch. Perhaps that person is just wealthy through hard work, and others are jealous of his or her success. It is very clear from the book Prayer warfare by Olukuya (2004) that witchcraft is probably blamed for most misfortunes or bad things that happen to people such as car accidents, stress, polygamy, death and poverty. This makes it very difficult for people who see witchcraft as the source of such misfortune to accept the blame for their own mistakes or misconceptions.

\section{Pastoral suggestions Biblical teaching on witchcraft}

Semenya and Letsosa (2012), who did a thorough study of the scriptural teaching concerning witchcraft, indicate clearly that God did not only condemn witchcraft, but he also punishes the sin of those who do not want to repent from practicing it (Mi 5:11). From Micah's perspective, witchcraft is a form of human fabrication and not a gift from God, and hence God promised to destroy and remove those who practice it amongst the Israelites. Revelation 9:20-21 warns that lack of repentance from sin, including the sin of witchcraft, will lead to destruction. Peter's response to Simon the sorcerer in Acts $8: 2-5$ demonstrates that the biblical teaching is against all forms of witchcraft. In Acts 19:19, there is an indication that witchcraft is conquered when sorcerers brought their scrolls together and burnt them publicly. I am in agreement with the view that witchcraft is in no way part of the Christian faith, and biblical passages like Ephesians 6:10-20 have some leading elements of the classic mode of the spiritual warfare. Koch (1976:85) is correct when saying that believers have the assurance that victory is only in the name of Christ, who overcame the powers of darkness on the Cross.

The Bible does, however, state how people are expected to live with one another, witches included. Exodus 22:18 is one of the biblical verses that emphasises and confirms the existence of witchcraft. It says: 'You shall not suffer the witch to live.' The fact that, by biblical accounts, witches exist does not imply that they should not be treated as human beings who have a right to live. Even though some people might think it is unjust that the witches go unpunished, either by law or whosoever, it is the biblical teaching towards Christians that we are expected to love all people, including our enemies. In that vein, people need to understand that they are not allowed to kill or destroy the life of an individual, even if this person is involved in witchcraft. Whether they ought to be punished by law or not, that will be determined by the law whilst our Christian responsibility is to continue to love and pray for them. Christians are now allowed to condemn or to judge.

Instead these people should place their trust in and dependence on God because God can protect them from being 'bewitched' by the witches who seek to harm them. In fact, my argument here is that, instead of seeking protection from a fellow human being in the form of either a sangoma or diviner, people should seek refuge and protection from God who created all human beings. Perhaps it is important to emphasise that trusting in God means, amongst other things, to trust in prayer and to have faith that he is able protect his children. Despite the fact that we read about magic, witchcraft and sorcery amongst both Jews and Greeks, the God of the Bible always discouraged and warned those who practiced it strongly.

\section{The role of psychological effect of witchcraft in human lives}

Counselling and exploring fears, worries or concerns with the patient or victim may help to relieve pain (Phaswana 2008:81). It is because pastoral caregivers pay scant attention to the physical and psychological aspects of witchcraft that the fear of witchcraft grows. Human touch, either through prayer (laying the hands on someone) or traditional African ways of healing, gives people hope and the belief that the pastor's touch has protected them from evil spirits. This is one of the reasons why many black Christians are flocking to African Independent Churches as well as Pentecostal churches where the pastors lay hands on them and pray for protection for these people and their personal belongings. In the African context, the Christian pastor or pastoral counsellor is seen to replace the medicine person's role in the life of his or her Christians by being a counsellor and a healer (Waruta \& Kinothi 2004:93). For me, prayer is more protective than seeking other fellow human beings like diviners and sangomas for protection. That is why I support the idea that, in many Christian churches, particularly the 
Pentecostal and charismatics, the pastor will be expected to pray for the church members in whatever way the church is used to pray. It is in this context where I think the pastor must lay hands on those who believe that it works for them.

\section{Communal counselling}

The beauty of African communalism, which Van der Walt (1997) articulates, is that the possible counselling model to be employed in the case of witchcraft should be a communal one. Kotze (1990) acknowledges that, in order to merely survive, African people have to depend on one another and cooperate in the same situation of deprivation. Because of this, people live with a collective consciousness where their decisions affect one another. Therefore the issue of communalism is the starting point whenever one wants to try to teach or change the lives of the African people. They cannot easily be dealt with or worked with in isolation. This is why Phaswana's research is of particular relevance to this article. He believes that pastoral counsellors should realise and acknowledge the richness within the African counselling models such as when the elders of the community meet together as ' $d z u l o$ ' or 'khoro' (meaning traditional courts or gatherings by local elders) to discuss their marriage problems (Phaswana 2008:40). If the traditional ways of solving the problems have been successful, the African pastoral caregivers should not just dismiss them but should utilise them to help those in trouble. Seen in this light, the main focus of pastoral care should be to heal people spiritually, mentally, psychologically and physically, regardless of the mode of counselling applied. The Ralushai Commission (Ralushai et al. 1996:60) also recommended that the government tread carefully around the issue of the role of chiefs in witchcraft-related practices and ritual killings. Their role as community leaders can fit in well with the communalbased counselling model, particularly because they are experienced in dealing with such practices.

\section{Power of prayer}

I agree with Waruta and Kinothi (2000:94) that divination and other magical practices in which traditional people engage to avert witches must be replaced by prayer, counselling, the Christian rite of confession and the acceptance of the use of charismatic gifts just as Paul teaches in 1 Corinthians 12:4-11. The pastoral teaching needs to indicate that prayer is more protective than the traditional methods of ukuziqinisa, ku biya muti or lenaka (meaning to prevent witches from entering a family). Olukoya (2004:42) discusses and introduces the prayer that destroys the evil spirit's power and casts out demons. Jesus Christ himself already indicated that prayer is the weapon given to humankind to conquer temptation and all types of evil (Gethsemane prayer in Mk 14:38). Omartian and Hayford (2003:130) refer to such prayers as 'a force that is irresistible'. The prayers to resist the evil spirits should be more of a spiritual warfare. In explaining spiritual warfare, Baxter and Lowery (2006) state:

Spiritual warfare is a lifestyle, not just an occasional event of rebuking the enemy or casting out demons. The believer must be spiritually prepared at all times. He or she must understand that since the enemy is continually on the prowl seeking who to devour, he must maintain an ongoing warrior's awareness of the spiritual battle. (p. 111)

This is what Jesus meant when he said that some demons cannot be averted if not through fasting and prayers (Mt 17:21). In Genesis 18:16-19:29, when Abraham prayed for Sodom in order to spare his nephew Lot and his family, he asked God if he would spare him for the sake of 50 righteous people and God promised that he would. Omartian and Hayford (2003:147) argue that God never stopped promising to save the people even when Abraham's number went down to ten, but God only stopped conceding when Abraham stopped. This means that perseverance in prayer is something that pastors and preachers should instil in the minds of people in order to avoid the fear of witchcraft. I support the dedication prayer for houses, cars and other possessions when called to do so because I see nothing wrong (from the biblical point of view) with such prayers, particularly because the owners of the property believe that such prayers will protect them and their personal belongings from the attacks of witches. Even though the prayer may seem to imply that one believes in witchcraft, the crux of the matter is that it is better to pray for those who believe that it will protect them than doing nothing, which may in turn make them believe that consulting other sorcerers will help them. Prayer is also a way of fighting the belief in witchcraft whilst replacing it with believe in God. There is nothing against such practices in the Bible.

\section{Conclusion}

Witchcraft has been a threat to Africans irrespective of their cultural background or religious affiliation. Some people think that, to allay their fears, they need to stone and burn to death those whom they suspect of being witches. Although many people use different ways to find out who the witch is, it remains difficult to prove from amongst the people who the witch is. Others think that they should consult witchdoctors who will come to put some protective measures in their homes and on their property to save them from the witches. Some Christians also fall in this group because they do not trust that the power of God alone is enough to prevent even the witches from attacking them. The third group belong to the AIC churches, and they also use some ritual means to ward off witches. Even in this group, some Christians are found consulting with inyangas and traditional healers for prevention and healing. The last group consists of Pentecostal and charismatic Christians, who believe that the powers of prayer and fasting are enough to scare the witches away. I would personally prefer to be part of the last group since we as believers trust that God's power is stronger than the powers that the witches possess. God's power manifests in prayer, and it is my belief that those who pray to him in faith will receive his answer.

\section{Acknowledgements Competing interests}

The author declares that he has no financial or personal relationship(s) that may have inappropriately influenced him in writing this article. 


\section{References}

Ashforth, A., 2005, Witchcraft, violence and democracy in South Africa, University of Chicago Press, Chicago, IL.

Associated Press, 1999, 'Witchcraft problem in South Africa', viewed 05 March 2013 from http://www.culteducation.com/reference/african_sects/african_sects8.html

Baloyi, M.E., 2010, 'Pastoral care and the agony of female singleness in the African Christian context', In die Skriflig/In Luce Verbi 44(3/4), 723-742. http://dx.doi. org/10.4102/ids.v44i3/4.169

Baxter, M.K. \& Lowery, T.L., 2006, A divine revelation of spiritual warfare, Whitaker House, New Kensington, PA.

Bureau of Democracy, Human Rights and Labor, 2001, Country reports on human right practices, viewed 05 March 2013, from http://www.state.gov/j/drl/rls/hrrpt/2001/

Carstens, P.A., 1986, 'The cultural defence in criminal law: South African perspectives', Harvard Law Review 99, 1293. http://dx.doi.org/10.2307/1341255

Dovlo, E., 2007, 'Witchcraft in contemporary Ghana', in G. Ter Haar (ed.), Imagining evil: Witchcraft beliefs and accusations in contemporary Africa, pp. 76-112, Africa World Press Inc., Trenton, NJ.

Felicia, N., 2001, 'Blending voodoo, witchcraft and Christianity', in Kjos Ministries, viewed 27 November 2012, from http://www.crossroad.to/Quotes/spirituality/Africanwitchcraft.htm

Gijswijt-Hofstra, M., 1999, Witchcraft after the witch-trials, Athlone Press, London.

Harries, J., 2010, 'Witchcraft, culture and theology in African development', African Nebula September, 138-152.

Igwe, L., 2012, 'Evangelical churches and epidemic of witchcraft accusations, Part 2', in James Randi Education Foundation, viewed 28 January 2012, from http://www.randi. $\mathrm{org} / \mathrm{site} /$ index.php/swift-blog/1592-evangelical-churches-and-the-epidemic-ofwitchcraft-accusations-part-2.html

Kekana, S., 2012, 'Naked muthi man in church', Daily Sun, 27 November, 2012, pp. 1-2.

Kgatla, S.T., 1995, 'Remaining prophetic in a time of reconciliation and development', report delivered during the Annual General Meeting of the Institute for Contextual Theology, Braamfontein, Johannesburg, 06 July, pp. 1-45.

Koch, K.E., 1976, Occult bondage and deliverance, Kregel, Grand Rapids, MI.

Kotze, J.C., 1990, 'Science as effective social communication: Subjectivity and possible world of common-sense reality', Communicare 9(2), 40-62.

Leff, D., 2010, 'Troubled souls', viewed 05 March 2011, from www.pagancouncil.co.za/ node

Leff, D., Fontleve, M. \& Martin, L., 2001, A pagan witches touchstone: Witchcraft and witch-hunts in South Africa, in South African Pagan Rights Alliance, viewed 01 witch-hunts in South Africa, in South African Pagan Rights Alliance, viewed 01
October 2009, from http://www.paganrightsalliance.org/documents/A_Pagan_ October 2009, from http:
Witches_Touchstone.pdf

Lundell, P.N., 2001, Armed for battle, Christian Art Publishers, Kansas City, MO.

Maboea, S.I., 2002, The influence of life-giving power in the African traditional religion and the Zionist Churches, CB Powell Bible Centre, UNISA, Pretoria.

Makhubu, P., 1988, Who are the independent churches?, Skotaville, Johannesburg.

Makisto, 2011, '3rd degree spotlight on witchcraft', in TVSA, viewed 05 March 2013, from http://www.tvsa.co.za/default.asp?blogname=FranklySpeaking\&articleID=17585

Manala, M.J., 2004, 'Witchcraft and its impact on black African Christians: A lacuna in the ministry of the Hervormde Kerk in Suidelike Africa', HTS Teologiese Studies/ Theological Studies 60(4), 1491-1510. http://dx.doi.org/10.4102/hts.v60i4.635

Maponya, F., 2011, 'Witchcraft accused flee', Sowetan, 14 March, 2011, p. 7.

Mashaba, S., 2012, 'Witches killing, destroying us: Accused live at police station', Sowetan, 23 November, 2012, p. 2.

Moloto, M., 2010, 'Mob murders "witchcraft priest"', IOL News, viewed 05 March 2013, from http://www.iol.co.za/news/crime-courts/mob-murders-witchcraftpriest-1.1006631\#.Uu-DWfu1uOg

Mpumalanga Witchcraft Suppression Bill, 2007, viewed 04 March 2013, from http:// methodius.blogspot.com/2007/07/mpumalanga-witchcraft-suppression-bill.html

Msomi, V.V., 2008, Ubuntu contextual African pastoral care and counselling, CB Powell Bible Centre, UNISA, Pretoria.
Mulaudzi, H., 2011, 'Cops warn of new witchcraft trend', Breaking News Africa, viewed 05 March 2013, from www.breakingnewsafrica.co.za/limpopo-police-warn-new05 March 2013, fron
witchcraft-trends

Muthambi, P., 2010, 'Food poisoning laid to rest', ZoutNet, viewed 20 January 2012, from http://www.zoutnet.co.za/details/16-07-2010/food_poisoning_victims_laid_ to_rest/8418

Mwalwa, M., 1999, 'The reality of witchcraft: Pastors must choose between two kingdoms and are mutually exclusive', The church leader in Africa: A training publication of African Ministry Resources 9(2), 6-7.

Nkhwashu, G., 2013, 'Jealous tokoloshe pokes me', Daily Sun, 27 February, 2013, p. 1. Ntlemo, B., 2012, 'Uproar over witchcraft', Sowetan, 27 January, 2012, p. 11.

Ntsan'wisi, H.W.E., 1985, Tsonga idioms - A descriptive study, Sasavona Publishers and Booksellers, Johannesburg.

Nyirongo, L., 1999, Dealing with darkness: A Christian novel on the confrontation with African witchcraft, IRS, Potchefstroom.

Okeja, U.B., 2010, 'Witchcraft and magic in African context', in Inter-Diciplinary.net, viewed 09 September 2012, from http://www.inter-disciplinary.net/wp-content/ viewed 09 September 2012, from
uploads/2010/02/okejapaper.pdf

Olivier, C.C., 1981, Die religie van die Gcaleka, Universiteit van Suid-Afrika, Pretoria.

Olukoya, D.K., 2004, Prayer warfare: 70 mad spirits, The Battle Cry Christian Ministries, Lagos.

Omartian, S. \& Hayford, J., 2003, The power of a praying church, Harvest House Publishers, Eugene, OR.

Oosthuizen, G.C., 1992, The healer-prophet in Afro-Christian churches, Brill, Leiden.

Oosthuizen, G.C., 1997, 'Indigenous Christianity and the future of the church in South Africa', International Bulletin of Missionary Research 21(1), 1-8.

Pauw, B.A., 1975, Christianity and Xhosa tradition: Belief and ritual amongst Xhosaspeaking Christians, Oxford University Press, Cape Town.

Petrus, T.S., 2009, 'An anthropological study of witchcraft-related crime in the Eastern Cape and its implications for law enforcement policy and practice', unpublished PhD dissertation, Faculty of Arts, Nelson Mandela Metropolitan University, Port Elizabeth.

Phaswana, D.R., 2008, 'Communal pastoral counselling: Culturally gifted care-giving in times of family pain - a Vhavenda perspective', unpublished PhD dissertation, Department of Practical Theology, University of South Africa, Pretoria.

'Police arrest 90 after Limpopo "witch-hunt", Mail \& Guardian, 2005, viewed n.d, from http://mg.co.za/article/2005-02-25-police-arrest-90-after-limpopo-witchhunt/

Ralushai, N.V., Masingi, M.G., Madiba, D.D.M., \& Van Den Heever, J.A., 1996, 'Report of the commission of inquiry into witchcraft and ritual murders in the Northern Province of South Africa, To: His Excellency the Honourable Member of the Executive Council for Safety and Security', Northern Province, South Africa.

South African Pagan Rights Alliance (SAPRA), 2011, 'Limpopo police warn of new witchcraft trends, viewed 06 March 2013', Times Live, from http://www.timeslive. witchcraft trends, viewed 06 March 2013', Times Live, from http://www.
co.za/local/2011/03/23/limpopo-police-warn-of-new-witchcraft-trends

South African Pagan Rights Alliance (SAPRA), 2013, Accusation is not proof, viewed 06 March 2013, from http://www.paganrightsalliance.org/advocacy/

Semenya, D.K. \& Letsosa, R., 2012, 'Biblical principles as an answer to the African people's questioning of witchcraft', Verbum et Ecclesia 33(1), 8 pages. http://dx.doi.org/ 10.4102/ve.v33i.674

Setiloane, G.M., 1976, The image of God amongst the Sotho-Tswana, AA Balkema, Rotterdam.

Tangelder, J.D., 2003, 'Reformed reflections: Post-apartheid South Africa', in Reformed Reflections, viewed 04 March 2013, from www.reformedreflections.ca/series/ Reflections, viewed
south-africa-7.html

Trapido, M., 2010, 'Make witchcraft a criminal offence', in Thought Leader, viewed 13 January 2013, from http://www.thoughtleader.co.za/traps/2010/01/13/makewitchcraft-a-criminal-offence/

Van der Walt, B.J., 1997, Afrocentric or Eurocentric? Our task in a multicultural South Africa, IRS, Potchefstroom.

Van Hunks, 2002, The tokoloshe-Africa's brownie, viewed 06 March 2013, from http:// www.vanhunks.com/tokoloshe1.htm

Waruta, D.W, \& Kinothi, H.W., 2004, Pastoral care in African Christianity, Acton Publishers, Nairobi. 